\section{Rediscovery of Small Salmon Arab Colotis amata Fabricius (Lepidoptera: Pieridae) from saline and semi-saline areas of West Bengal, India}

\section{Soumyajit Chowdhury ${ }^{1} \&$ Rahi Soren ${ }^{2}$}

${ }^{1}$ School of Oceanographic Studies, Jadavpur University, Kolkata, West Bengal 700032, India

${ }^{2}$ Dept. of Zoology, University of Calcutta, Kolkata, West Bengal 700019, India

Email: wildlifesc@gmail.com

The Small Salmon Arab, Colotis amata (Fabricius 1775), is a widely distributed butterfly, recorded from Africa and Asia. In South Asia, it occurs in India, Pakistan and Sri Lanka. In India, the species has been reported from all parts, except the Northeast (Wynter-Blyth 1957). The larval host plants are Salvadora oleoides, S. persica and Azima tetracantha (Salvadoraceae) (Wynter-Blyth 1957). In this article we report the occurrence of Colotis amata (Fabricius 1775) after 70 years in the saline areas of West Bengal.

\section{Observations}

The species was observed in thorny scrub jungles in three different parts of coastal West Bengal during the post-monsoon months (October-December, 2008).

The first record was on 26 October in the coastal areas of Sagar Island $\left(21^{\circ} 63^{\prime} \mathrm{N} \& 88^{\circ} \mathrm{O} 8^{\prime} \mathrm{E}\right)$ in the Sundarbans region of South 24 Parganas district. A single male individual was first observed flying low over hedges along a roadside. Later it settled on a sunny patch of ground with wings open

On 29 November, another specimen was recorded from a coastal scrub jungle in Haldia $\left(22^{\circ} 03^{\prime} \mathrm{N} \& 88^{\circ} \mathrm{O5}{ }^{\prime} \mathrm{E}\right)$, an industrial township in East Midnapur district. Here a few of them were dispersed. Males preferred sunny areas, while a couple of females were feeding on flowers. The third observation was on 7 December in Piyali $\left(22^{\circ} 39^{\prime} \mathrm{N} \& 88^{\circ} 48^{\prime} \mathrm{E}\right)$, an inland saline area, close to Canning in South 24 Parganas

Date of online publication 26 June 2009

ISSN $0974-7907$ (online) | 0974-7893 (print)

Editor: Peter Smetacek

\section{Manuscript details:}

Ms \# 02127

Received 28 January 2009

Final received 29 April 2009

Finally accepted 04 June 2009

Citation: Chowdhury, S. \& R. Soren (2009). Rediscovery of Small Salmon Arab Colotis amata Fabricius (Lepidoptera: Pieridae) from saline and semi-saline areas of West Bengal, India. Journal of Threatened Taxa 1(6): 351-352.

Copyright: (c) Soumyajit Chowdhury \& Rahi Soren 2009. Creative Commons Attribution 3.0 Unported License. JoTT allows unrestricted use of this article in any medium for non-profit purposes, reproduction and distribution by providing adequate credit to the authors and the source of publication.

Acknowledgements: We thank Mr. Bulganin Mitra and Dr. Kumar Ghorpade for valuable suggestions. Dr. Ghorpade, Judhajit Dasgupta and Ayan Ghose provided information base.

\section{OPEN ACCESS | FREE DOWNLOAD}

district, which is cultivated area, with a few scattered patches of thorny scrub. While feeding, the females open their wings slowly and close them in a few seconds. Males, as observed on previous

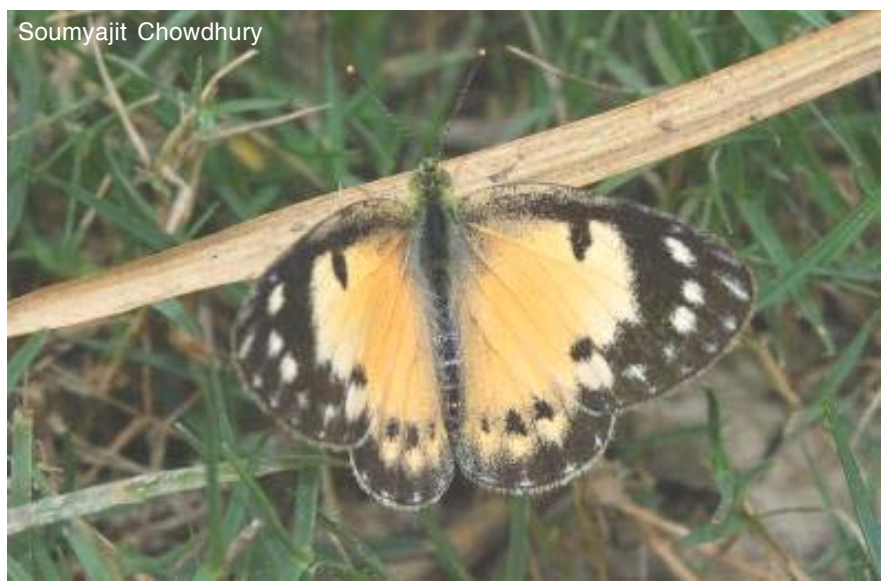

Image 1. Small Salmon Arab male showing upperside. photographed in Piyali, 7 December 2008.

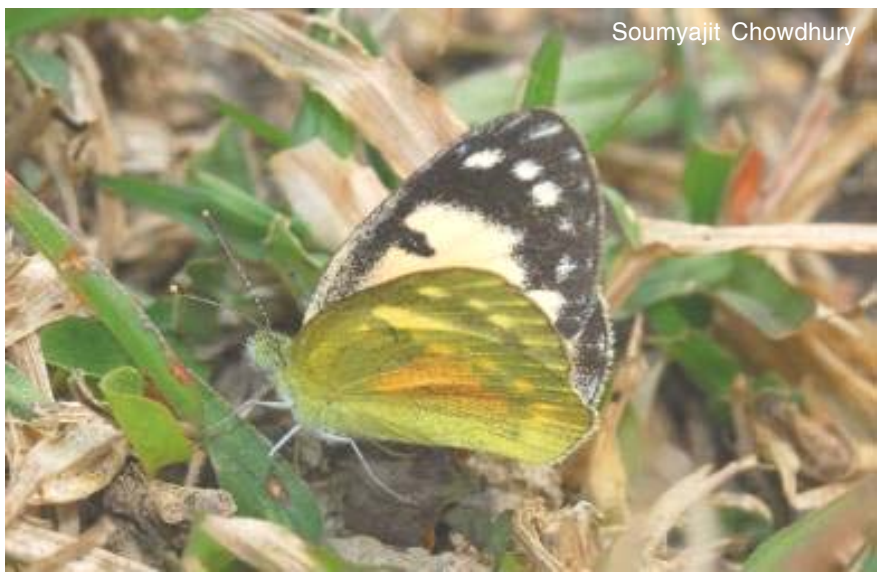

Image 2. Small Salmon Arab male showing underside. photographed in Piyali, 7 December 2008.

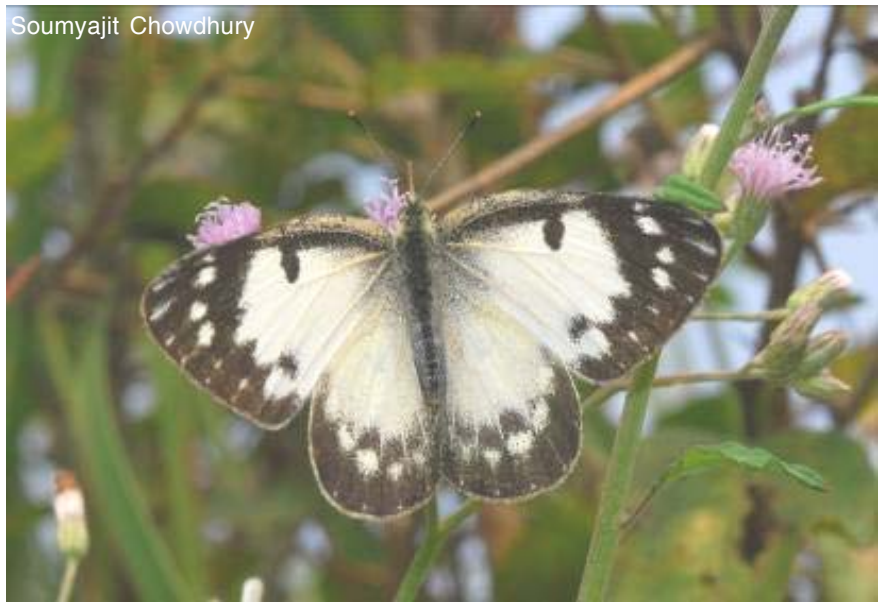

Image 3. Small Salmon Arab female showing upperside. photographed in Piyali, 7 December 2008. 
days, frequently settled on the ground with their wings open, particularly in sunlit patches. Both males and females are weak flyers and fly close to the ground.

\section{Discussion}

Bingham (1907) described C. amata, along with its larval host plants and distribution. He pointed out the absence of this species from the Bengal Presidency. Although Evans (1932) did not specify its occurrence in Bengal, Talbot (1939) reported it from Bengal. However, no specific locality in Bengal was mentioned. Sanders (1944-45) recorded that it "Presumably occurs" but he has not taken it near Calcutta. Ghosh and Chaudhury (1997) did not record C. amata during their faunistic surveys of West Bengal. However, they reported the species as a part of the review from literature. C. amata has been recorded only from the coastal (Sagar Island and Haldia) and inland saline (Piyali) areas of West Bengal so far. The present finding confirms the occurrence of the species in the eastern part of the Indian sub-region as well. Although the species has been reported to be 'common' in the Indian sub-region (Wynter-Blyth 1957; Kehimkar 2008), we found it to be locally rare in the saline and semi-saline areas of West Bengal.

\section{Conclusion}

Further studies will throw more light on the distribution pattern, host preference, seasonal variations and the impact of agriculture (as in Piyali) or urbanisation (as in Sagar Island and Haldia) on C. amata.

\section{References}

Bingham, C.T. (1907). Fauna of British India, including Ceylon and Burma. - Butterflies Vol I. Taylor and Francis, London, xxii + 511 pp.

Dasgupta, J. (2006). Paschimbanglar Projapoti (in Bengali). Ananda Publishers, Kolkata, 235pp.

Evans, W.H. (1932). The Identification of Indian Butterflies (2nd Edition). Bombay Natural History Society, Bombay, 464pp.

Ghosh, S.K. \& M. Chaudhury (1997). Insecta: Lepidoptera : Pieridae, pp. 705-728. In : Director, Zoological Survey of India (ed). State Fauna Series 3: Fauna of West Bengal, Part 7, Zoological Survey of India, Calcutta, 793pp.

Kehimkar, I. (2008). Book of Indian Butterflies. Bombay Natural History Society and Oxford University Press, Mumbai and Delhi, 513pp.

Sanders, D.F. (1944-45). A List of, and Notes on, Butterflies of Calcutta. Journal of the Bengal Natural History Society 19(2): 29-41.

Talbot, G. (1939). Fauna of British India, including Ceylon and BurmaButterflies, Vol. 1 (Repr. 1975). Today and Tomorrow's Printers and Publishers, New Delhi, xxix + 600pp.

Wynter-Blyth, M.A. (1957). Butterflies of the Indian Region. Bombay Natural History Society, Bombay, India, 523pp. 